\title{
Effects of food availability and habitat features on the Ephemeroptera species composition at seasonal and spatial scales from neotropical floodplain rivers
}

\author{
S. M. Melo ${ }^{*}$, F. H. Ragonha ${ }^{b}$, G. D. Pinha ${ }^{b}$, and A. M. Takeda ${ }^{b}$ \\ ${ }^{a}$ Faculdade de Tecnologia Prof. Fernando Amaral de Almeida Prado - FATEC, Av. Prestes Maia, 1764, Jardim Ipanema, \\ CEP 16052-045, Araçatuba, SP, Brazil

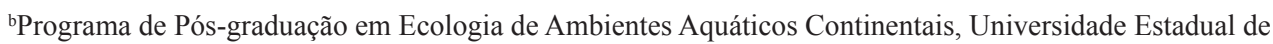 \\ Maringá - UEM, Av. Colombo, 5790, CEP 87020-900, Maringá, PR, Brazil \\ *e-mail: sandrammelo@yahoo.com.br
}

Received: August 31, 2016 - Accepted: October 3, 2016 - Distributed: February 28, 2018

(With 5 figures)

\begin{abstract}
Brazilian floodplains have suffered great changes in their natural characteristics in recent decades, mainly in the flood pulse. The Upper Paraná River floodplain is one of the few places where are found remained areas in which such peculiar characteristics keep reflecting on its high biodiversity. Ephemeroptera nymphs are one of the higher density groups among benthic community, occurring in many water bodies like large rivers and secondary channels. We sought to understand which factors are needed for the species establishment and how much important is the species colonization, especially in environments with anthropogenic changes. The marginal areas, which are more structured with presence of macrophytes, showed the highest density and richness even in the Paraná River that has great human impact. We verified dominance of Americabaetis alphus, Tricorythopsis araponga, Tricorythopsis artigas on the Parana River, correlated with transparency, depth and electric conductivity, while the dominance of Traverella sp. was correlated with water temperature, especially in marginal areas. Consequently, the increasing transparency and electric conductivity due to the Porto Primavera dam in Parana River can be favoring those Ephemeroptera species. We demonstrated the importance of preserving the wetlands of Ivinhema River State Park mainly for Guajirolus sp., which was only registered in this region. Therefore, our study provides support for understanding gaps from previously studies using artificial substrates in three large rivers which are of great importance to the upper Paraná River floodplain.
\end{abstract}

Keywords: zoobenthos, insect nymphs, colonization, biodiversity, richness.

\section{Efeitos da disponibilidade de alimento e características do habitat sobre a composição de espécies de Ephemeroptera nas escalas sazonal e espacial de rios de planície neotropicais}

\begin{abstract}
Resumo
Muitas planícies de inundação brasileiras vêm sofrendo enormes alterações em suas características naturais nas últimas décadas, principalmente no pulso de inundação. A planície de inundação do alto rio Paraná é um dos poucos lugares onde ainda há áreas nas quais essas características peculiares se mantêm, o que reflete em sua alta biodiversidade. Dentre a comunidade zoobentônica, Ephemeroptera é um dos grupos com maior densidade, ocorrendo em diversos corpos aquáticos como rios de grande porte e canais secundários. Nós buscamos compreender quais fatores são necessários para o estabelecimento das espécies e o quão importante é a colonização dessas espécies, principalmente em ambientes com modificações antrópicas. As áreas marginais mais estruturadas com presença de macrófitas apresentaram altas densidade e riqueza mesmo no rio Paraná que apresenta grande impacto antrópico. Verificamos que as dominâncias de Americabaetis alphus, Tricorythopsis araponga e Tricorythopsis artigas no rio Paraná foram correlacionadas com maiores valores de transparência, profundidade e condutividade, enquanto que a dominância de Traverella sp. foi correlacionada com temperatura, principalmente em áreas marginais. Consequentemente, o aumento da transparência e da condutividade devido à barragem de Porto Primavera no rio Paraná pode estar favorecendo essas espécies de Ephemeroptera. Nossos resultados demonstram a importância da preservação do Parque nacional das várzeas do rio Ivinhema, principalmente para o gênero Guajirolus sp., o qual apenas foi registrado nessa região. Portanto, nosso estudo vem trazer subsídios para compreensão de lacunas verificadas em estudos anteriores utilizando substratos artificiais em três rios de enorme influência na planície de inundação do alto rio Paraná.
\end{abstract}

Palavras-chave: zoobentos, ninfas de insetos, colonização, biodiversidade, riqueza. 


\section{Introduction}

Environmental laws aiming at surveying, managing and protecting freshwater ecosystems throughout the world rely on biological indicators of ecosystem health (Stoddard et al., 2008; Callisto et al., 2004). Natural preserved areas keep the integrity of a considerable number of aquatic ecosystems, which makes them of great importance for the maintenance of both biological diversity and structural patterns of these environments (Agostinho et al., 2005). Studies with these ecological perspectives have been conducted to better understand the interactions of organisms and functioning of aquatic ecosystems (Callisto et al., 2001; HenriquesOliveira et al., 2003; Suriano and Fonseca-Gessner, 2004; Silva et al., 2007).

Attempts to describe reference conditions based on the existence of pre-established characteristics in a range of sites have become very usual over the past three decades. In such approaches, sites have been classified in groups by clustering methods, which are based on the similarity of their species composition, providing an objective way of grouping reference sites with similar invertebrate assemblages (Reynoldson et al., 1997). In aquatic environments, studies about macroinvertebrate distribution from lotic environments has generated great interest, so that many of the general functional models of stream and river ecology were derived from studies of this fauna (e.g., "River Continuum Concept" - Vannote et al., 1980 and "Serial Discontinuity Concept" - Ward and Stanford, 1983).

Special attention must be paid to the assessment of the distribution and structure of the aquatic communities, the diversity of habitats and microhabitats and available trophic resources. Many aquatic insects are rapid colonizers because their active aerial dispersal (for review, see Power et al., 1988; Flory and Milner, 2000). However, several years of study are necessary for a confident evaluation of the aquatic biodiversity at the species level and it is of great importance starting this approach with the characterization of abiotic parameters and an inventory of aquatic communities.

Benthic invertebrates play an important role in riverine food chains and organic matter cycling, so that the environmental parameters shaping their assemblages have been studied in many ecosystems. The structure and composition of lotic macroinvertebrate communities are known to depend on both biotic and abiotic characteristics of habitat. Ephemeroptera is an important group among macroinvertebrates, presenting great abundance and diverse and occupying a large variety of aquatic environments, from running water to backwater (Salles et al., 2004a). This group of aquatic insects contains approximately 4,000 species in 300 genera, distributed worldwide, except at the poles and oceanic islands (Domínguez et al., 2001). In Brazil, there is a total of 10 families, 63 genera and 166 species of Ephemeroptera (Salles et al., 2004a). Ephemeroptera nymphs are, in general, considered to be sensitivity to environmental changes (Lenat, 1988), being widely used in monitoring programs.
Environmental conditions may vary among watersheds of large river basins, such as the different rivers from the Upper Paraná River floodplain. Abiotic differences consequently exert influences on the Ephemeroptera community. In this study, we looked at Ephemeroptera community under different conditions of food availability and habitat features at two scales: seasonal and spatial. Possible relationships between faunal variation and environmental parameters were examined. Based on these assumptions, we expected to find differences in both composition and structure of the Ephemeroptera nymphs in relation to differences in the environmental conditions from each studied river.

\section{Material and Methods}

\subsection{Study area}

This study was conducted in the Upper Parana River Floodplain (Paraná, Brazil). The sampling area is located between Três Lagoas (Mato Grosso do Sul State, Brazil) and Guaíra (Paraná State, Brazil) towns, and Porto Primavera and Itaipu dams, a stretch of approximately $230 \mathrm{~km}$ extension, covering an area of 526,752 ha (Souza Filho and Stevaux, 1997). Samples were collected at 12 regions, within of three rivers: Paraná, Ivinhema and Baía (Figure 1).

The Paraná River basin is the second major basin in South America, encompassing an area about $20.000 \mathrm{~km}^{2}$ in the maximum flood period (Welcomme, 1985; Bonetto et al., 1989). From its headwater, at the confluence of Grande and Parnaíba rivers (lat. $20^{\circ} \mathrm{S}$ ) to its mouth at the la Plata river in Argentina (lat. $34^{\circ} \mathrm{S}$ ), Paraná River runs about $3,780 \mathrm{~km}$. This river presents a varying width, with the occurrence of islands and bars. The maximum depth can overcome 15 meters and its marginal vegetation is composed by grassland, and scattered trees, remnants from original vegetation. Moreover, some marginal areas and islands present signs of human exploration.

Baía River ( $\left.22^{\circ} 41^{\prime} 9^{\prime \prime} \mathrm{S} ; 53^{\circ} 15^{\prime} 9^{\prime \prime} \mathrm{W}\right)$ is located at the right margin of Paraná River, into the Mato Grosso do Sul State. This river presents varying widths and depth about 3.2 meters, with stretches narrower and upper margins, which are occupied by riparian vegetation or human-altered grassland. At the wider sections, the margins are shorter and the vegetation is composed by flooded grasslands, named as "várzeas". The Baía River is a meandering river that can be considered as a "semi lotic" environment, presenting patterns of thermal stratification in the water column (Thomaz et al., 1991).

Ivinhema River (2255’2”S; 5339'1”W) runs parallel to Paraná River and it is linked to Baía River by Curutuba channel and to Paraná River by Ipoitã and two other channels in its lower portion. It presents an average depth of 3.9 meter, shows distinguished vegetation in its margins, varying from herbaceous to extensive areas covered by riparian forests in different stages of regeneration. This region is characterized by the presence of hundreds of lakes (Stevaux et al., 1997) (Figure 1). 


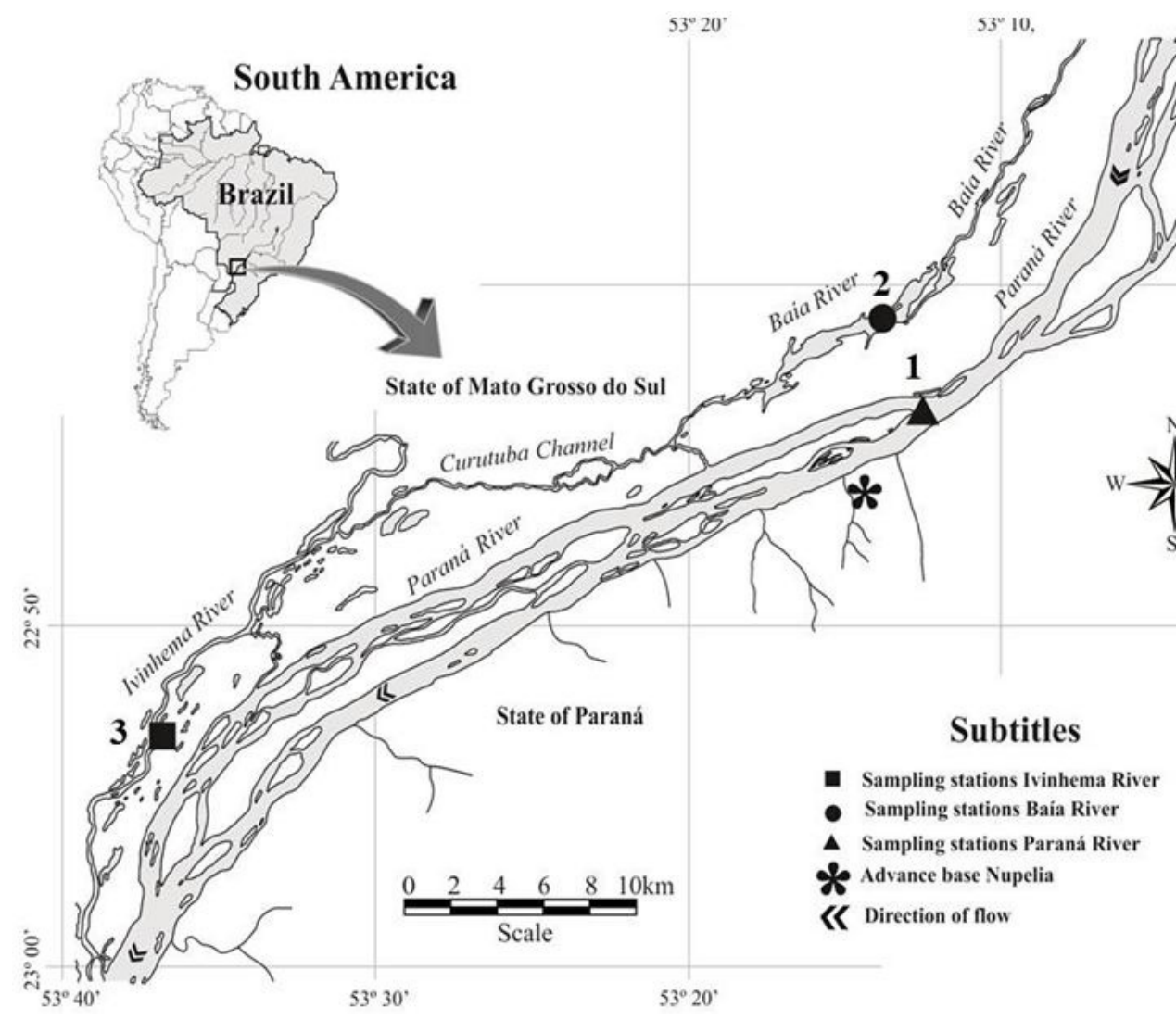

Figure 1. Sampling stations of the Upper Parana River floodplain. 1- Parana River (main channel); 2- Baia River (main channel), 3- Ivinhema River (main channel).

\subsection{Sampling}

For study of Ephemeroptera distribution on the artificial substrates, the replicates were monthly sampled from January 2004 to March 2005 in Paraná, Baía and Ivinhema rivers. In each river were installed three sets of substrates (in transect of each river: right and left margins and central region). Each substrate set was composed by a float and 2 wooden substrates, totaling 1,215 samples ( 3 rivers $\times 3$ regions $\times 3$-substrate structures $\times 3$ replicates $\times 15$ months).

The material adhered to each substratum were sampled with a square tray of $5 \mathrm{~cm} \times 5 \mathrm{~cm}\left(0.0025 \mathrm{~m}^{2}\right)$, and fixed in polyethylene bottles containing $70 \%$ alcohol. For statistical analyses, we considered each set of substrates sampled monthly in each region (i.e., margins or center region into each river) as a sample unity. Concurrently to biological sampling, we measured the values of water temperature $\left({ }^{\circ} \mathrm{C}\right)$, electric conductivity $\left(\mu \mathrm{S} . \mathrm{cm}^{-1}\right)$ and dissolved oxygen concentration $\left(\mathrm{mg} . \mathrm{L}^{-1}\right)$ by YSI equipment $(6820 \mathrm{CM}$ model $)$, depth (meters), water transparency by Secchi disk and water flow $\left(\mathrm{cm} . \mathrm{s}^{-1}\right)$ by General Oceanics INC equipment (2035 MKIV model). The hydrometric levels from Paraná and Ivinhema rivers were provided by Itaipu Binacional Water Agency. For statistical analyses, the water levels were transformed in diary averages to verify the dry and flood events during the sampled period.
In the laboratory, we separated and counted the Ephemeroptera nymphs under a stereoscopic microscope. Later, we identified them at the lowest possible taxonomic level under an optical microscope, according to specialized literature of Dominguez et al. (2001), Salles et al. (2004b) and Dias and Salles (2005).

\subsection{Statistical analyses}

The replicated samples of nymph's density values between the stations were transformed in averages (ind. $\mathrm{m}^{-2}$ ) to verify spatial and temporal variations in Ephemeroptera community. We built two graphs, the former between three rivers (Paraná, Baía and Ivinhema rivers) and the later between the 15 months of colonization. To check the nymphs that dominated certain location or substrate, we calculated the Kownacki's dominance index (Kownacki, 1971). Analyses of Variance (ANOVA) were performed between the different Ephemeroptera attributes (density and richness) and the spatial (biological variation per rivers, sites regions and substrate types) and temporal scales (biological variation per months).

The more influential environmental data (limnological variables: temperature, dissolved oxygen, electric conductivity, $\mathrm{pH}$, transparency and depth) on the Ephemeroptera distribution and composition were used to explain the biological variables through a Canonical 
Correspondence Analysis (CCA). CCA was performed to search the probable correlations between environmental variables and abundance of Ephemeroptera species for the different analyzed scales (rivers and regions). The analysis was performed using PcOrd 5.0 program (McCune and Mefford, 1999).

\section{Results}

During the sampled period, we recorded only one total flood event (flood $>6 \mathrm{~m}$ ) in studied area, between January and February 2005. In March, April, June and November 2004 we observed shorter floods events $(3.5 \mathrm{~m}<$ flood $<4.5 \mathrm{~m})$, which could influence only the Paraná Subsystem (Souza Filho, 2009) (Figure 2).

We recorded 2,042 Ephemeroptera nymphs, representatives to five families (Baetidae, Leptohyphidae, Leptophlebiidae, Polymitarcyidae and Caenidae), identified in 16 taxa (Table 1). We verified significant differences in Ephemeroptera density for scales of the river and region, where Ivinhema and Paraná rivers were different to Baía (Figures 3A) and right margin region was different to center (Figure 3B), respectively. On the other hand, significant differences for richness were observed for river and temporal scales. Like density, Ivinhema and Paraná rivers presented major richness and were different to Baía (Figures 3A). In relation to temporal scale, the only period with major differences to others were comprised by $6-8^{\text {th }}$ months of colonization (Figure 3C).

We could detect some temporal pattern in Ephemeroptera densities only for Ivinhema River, which were decreasing from first to the last months. For the other rivers, the densities remained moderately constant along sampled period, exception of a high-density period in Baía River, between $8-10^{\text {th }}$ months. The major values of densities were registered at Paraná and Ivinhema rivers (Figure 4).

In relation to composition, the major differences were observed between Ivinhema and Paraná rivers. Despite the high abundance of Americabaetis alphus in all rivers and of its dominance in Ivinhema and Paraná rivers (Table 1), we

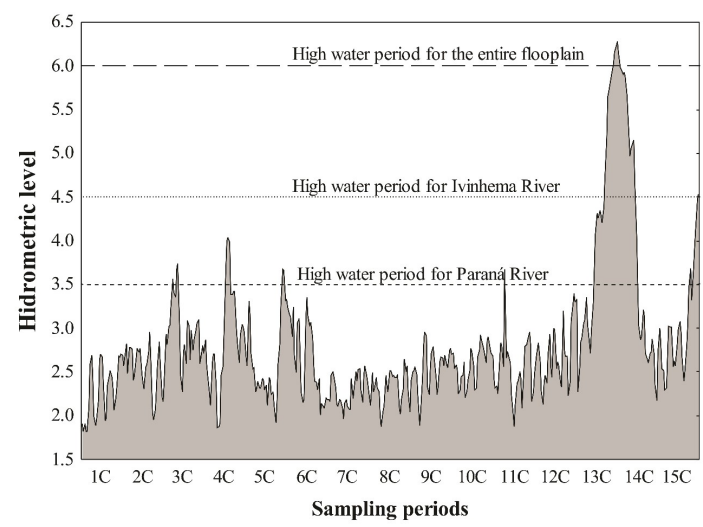

Figure 2. Hydrometric variations during the sampling period. observed higher densities and dominance of Tricorythopsis araponga in Paraná River, while Traverella sp. was the dominant taxa in Ivinhema River. In contrast, we observed other dominant taxa to Baía River, with Caenis sp. and Farrodes sp. as the most abundant taxa.

The correlations between environmental and biological data through Canonical Correspondence Analysis (CCA) was significant under the Mont Carlo's permutations (eigenvalue: 0.492 with $\mathrm{p}<0.01$ ), explainig $15 \%$ of data variations. We observed a clustering of two main groups (Figure 5A): the former group was composed by Ivinhema and Baía sampling sites, and was influenced by major values of temperature (Figure 5B) and dominances of
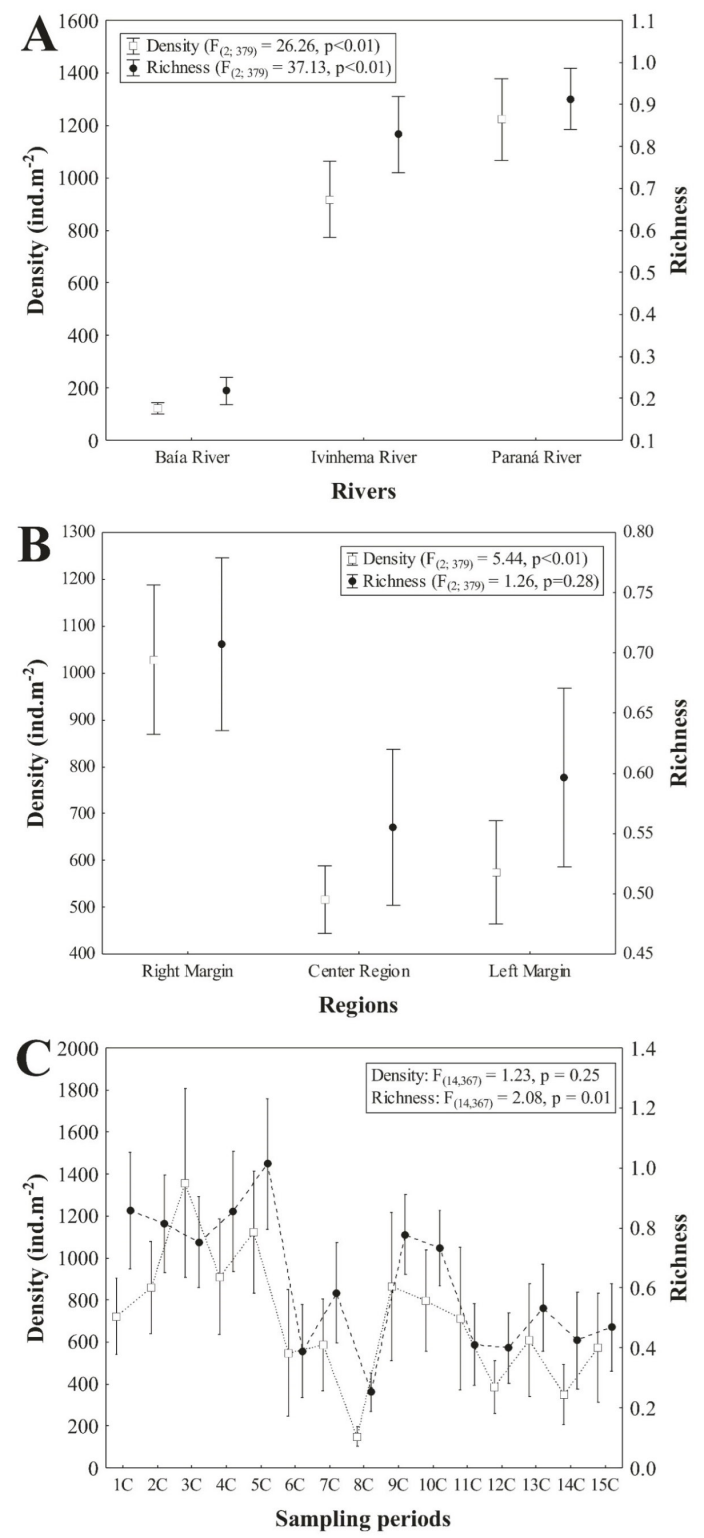

Figure 3. Analyses of Variance (One-way ANOVA) between rivers (A) regions (B) and sampling period (C). 


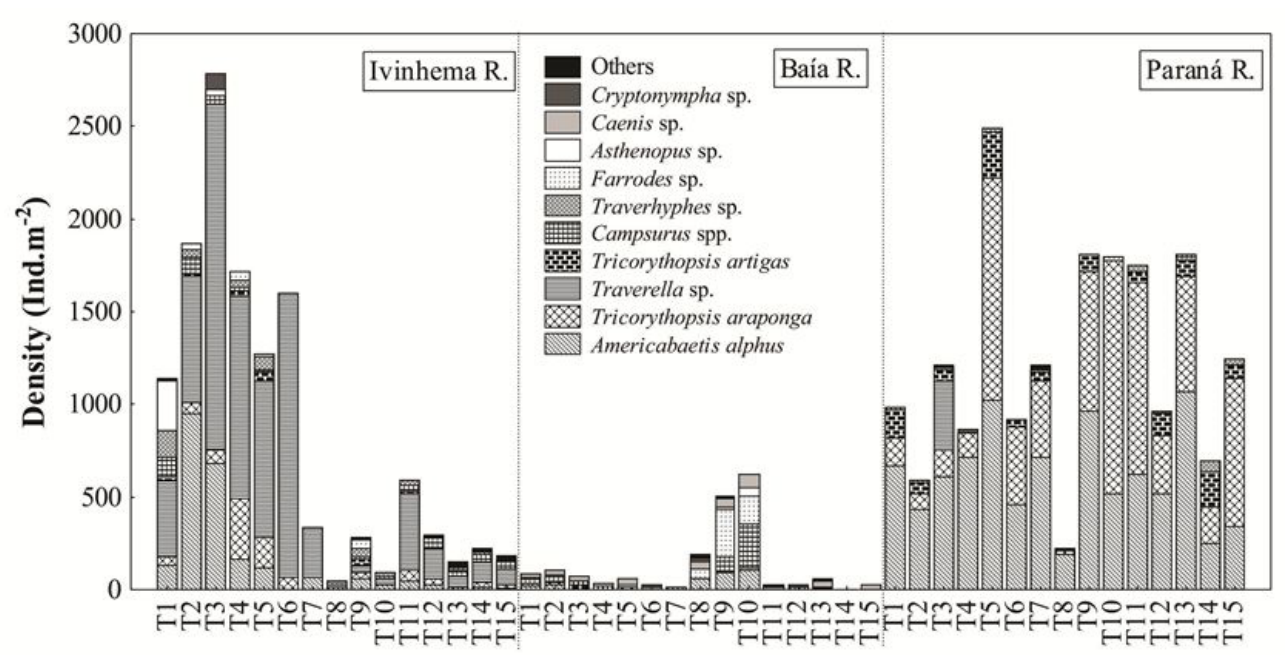

\section{Colonized months}

Figure 4. Ephemeroptera densities along of the 15 months of colonization in each sampled rivers.

Table 1. Kownacki's dominance index: in black: dominant taxa $(10<$ values $<100)$; Subdominant taxa $(1<$ values $<9$,99); non-dominant taxa $(0<$ values $<1)$; empty cells: taxa absent.

\begin{tabular}{|c|c|c|c|c|c|c|c|c|c|}
\hline & \multicolumn{3}{|c|}{ Ivinhema } & \multicolumn{3}{|c|}{ Baía } & \multicolumn{3}{|c|}{ Paraná } \\
\hline & $\mathbf{C E}$ & MD & ME & $\mathbf{C E}$ & MD & ME & $\mathbf{C E}$ & MD & ME \\
\hline \multicolumn{10}{|l|}{ Baetidae } \\
\hline $\begin{array}{l}\text { Americabaetis alphus (Lugo-Ortiz \& } \\
\text { McCafferty 1996) }\end{array}$ & 10.53 & 17.98 & 11.67 & 1.50 & 6.86 & 6.38 & 63.81 & 41.31 & 46.81 \\
\hline Camelobaetidius sp. (Demoulin 1966) & & & & & 0.20 & & 0.19 & & \\
\hline $\begin{array}{l}\text { Cryptonympha sp. (Lugo-Ortiz \& } \\
\text { McCafferty 1998) }\end{array}$ & & 0.16 & & 0.15 & & 0.57 & & 0.01 & 0.03 \\
\hline Guajirolus sp. (Flowers 1985) & & 0.11 & & & & & & & \\
\hline $\begin{array}{l}\text { Baetodes sp. (Needham \& Murphy } \\
\text { 1924) }\end{array}$ & & & & & & & & & 0.03 \\
\hline \multicolumn{10}{|l|}{ Leptohyphidae } \\
\hline $\begin{array}{l}\text { Tricorythopsis araponga (Dias \& } \\
\text { Salles 2005) }\end{array}$ & 6.75 & 3.42 & 2.27 & 1.35 & & & 16.05 & 51.94 & 7.63 \\
\hline Tricorythopsis artigas (Traver 1958) & 0.77 & 0.16 & 0.13 & 0.30 & & 0.14 & 0.03 & 1.10 & 20.72 \\
\hline Tricorythopsis minimus (Allen 1973) & 0.04 & & 0.03 & & 0.20 & 0.14 & & & \\
\hline Traverhyphes sp. (Molineri 2001) & 3.24 & 2.38 & 0.29 & & & & 0.06 & 0.22 & 0.94 \\
\hline Tricorythodes n. sp. (Ulmer 1920) & & & & & 0.20 & & & & \\
\hline \multicolumn{10}{|l|}{ Leptophlebiidae } \\
\hline Traverella sp. (Edmunds 1948) & 37.96 & 54.12 & 35.57 & & & & & & 0.78 \\
\hline Thraulodes sp. (Ulmer 1920) & & & 0.03 & & & & & & \\
\hline Farrodes sp. (Peters 1971) & 0.04 & 0.16 & 0.29 & 6.29 & 10.20 & 0.85 & 0.03 & & 0.03 \\
\hline \multicolumn{10}{|l|}{ Polymitarcyidae } \\
\hline Campsurus spp. (Eaton 1868) & 0.23 & 4.28 & 1.29 & 5.62 & 5.49 & 4.54 & & & \\
\hline Asthenopus sp. (Eaton 1871) & 0.81 & & 0.97 & 0.60 & 0.20 & 0.57 & & & \\
\hline \multicolumn{10}{|l|}{ Caenidae } \\
\hline Caenis sp. (Stephens 1835) & & & & 10.49 & 1.18 & 8.51 & & & \\
\hline
\end{tabular}



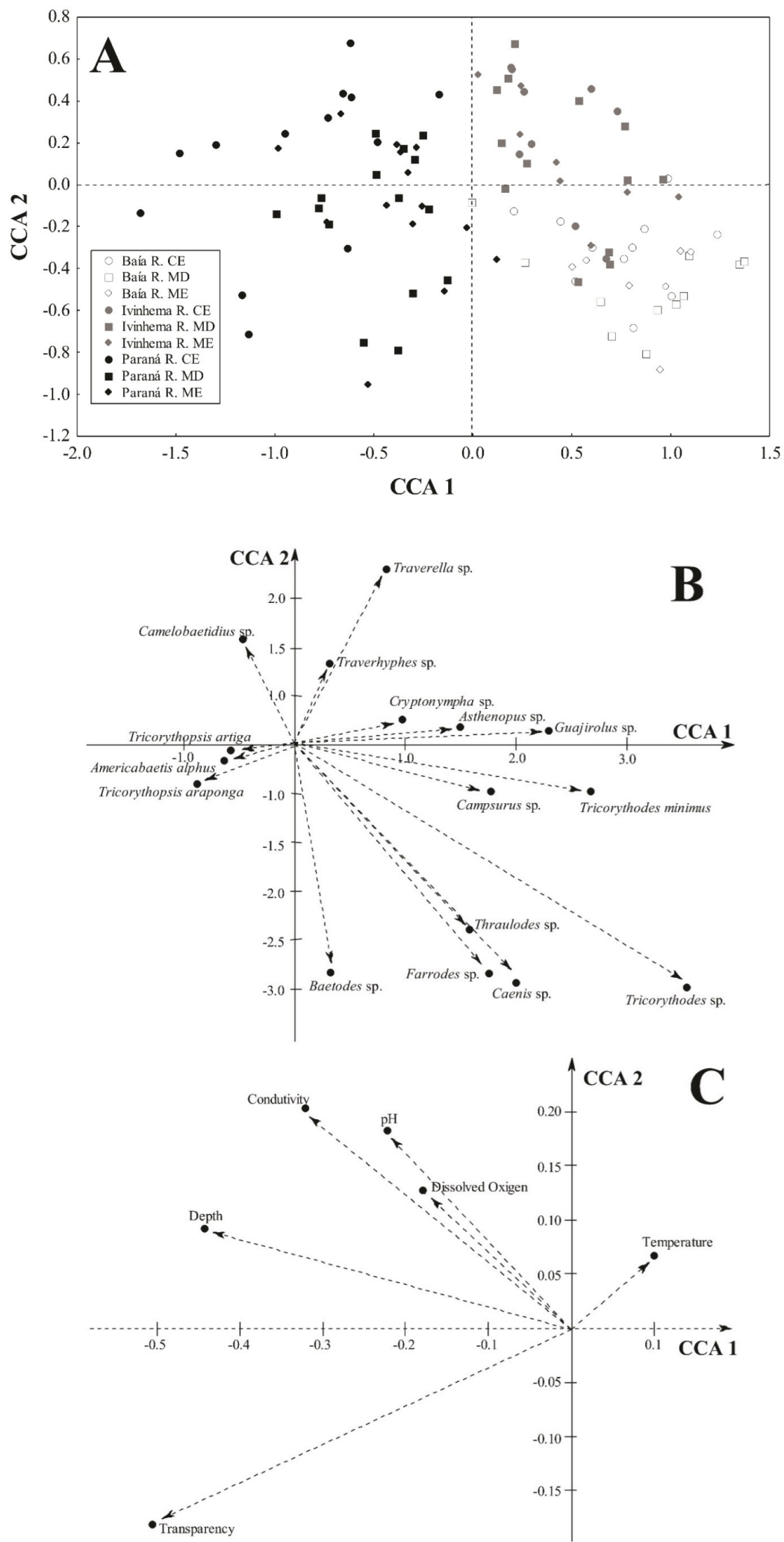

Figure 5. Ordination diagram for the first two axes of Canonical Correspondence Analysis (CCA) with the scores ordination of 1 and 2 axes of sampled sites (A) with the correlation of Ephemeroptera (B) and abiotic variables (C). 
Farrodes sp., Canis sp. (from Baía River), Tricorythodes sp. and Traverella sp. (from Ivinhema River; Figure 5C). The later group was composed by Paraná sampling units, by the major values of all other environmenal variables (mainly transparency, deph and eletric condutivity) and the dominance of Camelobaetidius sp., Tricorythopsis araponga.

\section{Discussion}

This study corroborated with our initial hypothesis that Ephemeroptera communities are structured under environmental patterns. Despite we had not observed temporal pattern, we could detect in this research the first records of many Ephemeroptera genera to Upper Paraná River floodplain area, such as, Baetodes sp., Camelobaetidius sp., Guajirolus sp. Tricorythodes sp., Traverhyphes sp., Traverella sp., Thraulodes sp. Farrodes sp. and Asthenopus sp.

The dominance of Americanbaetis alphus and Tricorythopsis araponga in Paraná River, added to the temporal stability, indicate that these species are mainly adapted in fast-flowing waterbodies as the Paraná River, which reached speeds up to $0.566 \mathrm{~ms}^{-2}$ during a flood events. The Baetidae nymphs are known by their high abundance in running waters (Berner and Pescador, 1988; Salles et al., 2004a), including species with high swimming ability (Mackay, 1992) and short life cycle in the tropics (Jackson and Sweeney, 1995).

Americabaetis alphus nymphs presents a high mobility on the substrates and its swimming is performed by muscular contractions of the abdomen and through the movements of the caudal filaments, which give support and strength to the movement. The morphology of the tarsal claws with denticles of $A$. alphus and two rows of submarginal denticles (Lugo-Ortiz and McCafferty, 1996), can favor the establishment of this species on the Paraná River substrates. Francischetti et al. (2004) in studies performed in Itatiaia River (Campo Belo- RJ) verified a greater abundance of $A$. alphus on litter streams. Moreover, according to Shimano et al. (2013), this species is associated with wood substrates in lotic and semi lotic environments.

Absences of A. alphus and T. araponga in both river bottom (Takeda et al., 1997; Takeda and Fujita, 2004) and macrophytes (Melo et al., 2002, 2004; Takeda et al., 2003), can suggest the coming of these nymphs to substrate by drifting in the water column, driven by strong Paraná River flow. Similar conditions were presented by the Ivinhema River, where we also observed a dominance of at least one of these species, A. alphus. A. alphus was dominant in Ivinhema and Paraná rivers but was not in Baía River, which presents an almost imperceptible flow (most of the movement of the float was caused by wind), indicating again the preference of this species by running waters.

The major transparency values of Paraná River (due to the presence of a reservoir cascade upstream of the studied area, which is holding most suspended sediment), might have also influenced the dominance of
A. alphus and T. araponga. The damming events usually favor the proliferation of periphyton algae that comprise food sources and shelter for these species, as verified by Brittain (1982) and Salles et al. (2003).

Generally, the abundance of a specific trophic resource determines the composition, diversity and abundance of invertebrate communities (Ward, 1992). Moreover, the substrate surface has greater physical irregularity, that provides more habitat and organic matter accumulation, which are important for obtaining food and shelter for invertebrates (Anjos and Takeda., 2005; Shimano et al., 2013). For instance, from field observations, we noted that Traverella sp. freely runs on the substrate surface and when there was some disturb event, the nymphs quickly seek for shelter within the substrate. Moreover, the quantity and quality of fine particulate suspended organic matter present in the environment may be related to the dominance of this species in the Ivinhema River.

Comparing the rivers, we observed a dominance of distinctive taxa in the Baía River. Such observations lead us to recognize the high species adaptation to differential environmental characteristics of each river, which showed differences in structure and composition of Ephemeroptera community. The semi-lotic conditions of Baía River can favor the abundance of some taxa, as Caenis sp., Campsurus sp. and Farrodes sp. Nolte et al. (1997), in studies conducted in the Benedict River, reported the occurrence of Caenidae family after a disrupting of water flow. The food resources are another important factor determining the abundance of Caenis sp. According to Palmer et al. (1993), this genera presents scraper habits. Although we do not evaluated the periphyton composition, we noted a high algae colonization under the substrate surfaces where such genera was found, which would provide an extra food source for these nymphs. High abundances of food resources related to algae could be allowed the abundance of Farrodes sp., classified by Polegatto and Froehlich (2001) as scrapers and filter-gatherers, able to get a wide variety of food resources available in the environment, such as diatoms and other algae, including colonial algae, fungi, debris, and fine particulate organic matter.

Campsurus sp. nymphs are found in both lentic and lotic environments (Edmunds and Waltz, 1996) and are known for their burring habits, digging galleries into substrates (Melo et al., 1993; Takeda et al., 1997; Leal et al., 2005; Domínguez et al., 2006). Despite these preferred bottom-habits, Campsurus sp. occurrence on artificial substrates can be related to vertical migration events, which is allowed by the absence of a high-water flow of Baía River, where this taxon was abundant. Vertical migrations of Campsurus spp. were also recorded by Melo et al. (2004), who related a migration pattern from the bottom to Eichhornia azurea substrates with periods of low oxygen concentrations.

Variations in limnological characteristics of the rivers, especially the flow rate, influenced the structure and composition of the Ephemeroptera community among the rivers sampled. In addition, differences in the availability 
of food resources and morphological constraints of each species were also important in determining differences in community structure among the studied rivers. Therefore, these features reflect the adaptive strategies of each group (such as body morphology to avoid drag by the current, mobility behavior and orientation and how to obtain food) to survive in different environmental conditions found between rivers.

Studies about colonization of insects on artificial substrates such as Ephemeroptera nymphs are extremely important for monitoring, conservation and management of aquatic environments. Our study adds information for this poorly studied group in large water bodies, such as the Upper Paraná River floodplain, demonstrating how the colonization and establishment patterns differ between environments. Therefore, we highlight the need to conduct experiments on appropriate scales of space and time, so that we can have an idea as close as possible to reality about the dispersal and colonization of these insects.

\section{References}

AGOSTINHO, A.A., THOMAZ, S.M. and GOMES, L.C., 2005. Conservação da biodiversidade em águas continentais do Brasil. Megadiversidade, vol. 1, pp. 70-78.

ANJOS, A.F. and TAKEDA, A.M., 2005. Colonização de Chironomidae (Diptera: Insecta) em diferentes tipos de substratos artificiais. Acta Scientiarum. Biological Sciences, vol. 27, no. 2, pp. 147-151. http://dx.doi.org/10.4025/actascibiolsci.v27i2.1325.

BERNER, L. and PESCADOR, M.L., 1988. The mayflies of Florida. Gainesville: University Press of Florida. 416 p. Revised edition.

BONETTO, A.A., WAIS, J.R. and CASTELLO, H.P., 1989. The increasing damming of the Paraná basin and its effects on the lower reaches. Regulated Rivers: research and management, vol. 4, no. 4, pp. 333-346. http://dx.doi.org/10.1002/rrr.3450040402.

BRITTAIN, J.E., 1982. Biology of mayflies. Annais Revista Entomology, vol. 27, no. 1, pp. 119-147. http://dx.doi.org/10.1146/ annurev.en.27.010182.001003.

CALlisto, M., GOULART, M., MEDEIROS, A.O., MORENO, P. and ROSA, C.A., 2004. Diversity assessment of benthic macroinvertebrates, yeasts, and microbiological indicators along a longitudinal gradient in Serra do Cipó, Brazil. Brazilian Journal of Biology = Revista Brasileira de Biologia, vol. 64, no. 4, pp. 743-755. PMid:15744414. http://dx.doi.org/10.1590/ S1519-69842004000500003.

CALlisto, M., MORETTI, M. and GOULART, M., 2001. Macroinvertebrados bentônicos como ferramenta para avaliar a saúde de riachos. Revista Brasileira de Recursos Hídricos, vol. 6, no. 1, pp. 71-82. http://dx.doi.org/10.21168/rbrh.v6n1.p71-82.

DIAS, L.G. and SALLES, F.F., 2005. Three new species of Tricorythopsis (Ephemeroptera: Leptohyphidae) from southeastern Brazil. Aquatic Insects, vol. 27, no. 4, pp. 235-241. http://dx.doi. org/10.1080/01650420500336657.

DOMÍNGUEZ, E., HUBBARD, M.D., PESCADOR, M.L. and MOLINERI, C., 2001. Ephemeroptera. In: H.R. FERNANDES and E. DOMÍNGUEZ, eds. Guia para la determinación de los artrópodos bentónicos sudamericanos. Califórnia: Universidade Nacional de Tucumán, pp. 17-53.
DOMÍNGUEZ, E., MOLINERI, C., PESCADOR, M.L., HUBBARD, M.D. and NIETO, C., 2006. Ephemeroptera of South América. In: J. ADIS, J.R. ARIAS, K. WANTZEN and G. RUEDA, eds. Aquatic Biodiversity of Latin America. Sofia: Pensoft Press, vol. 2, 322 p.

EDMUNDS, G.F.; WALTZ, R.D. 1996. Ephemeroptera. In: MERRIT, R.W.; CUMMINS, K.W., eds. An Introduction to thr Aquatic Insects of North America. Iowa: Kendall/Hunt publishing company.

FLORY, E.A. and MILNER, A.M., 2000. Macroinvertebrate community succession in Wolf Point Creek, Glacier Bay National Park, Alaska. Freshwater Biology, vol. 44, no. 3, pp. 465-480. http://dx.doi.org/10.1046/j.1365-2427.2000.00596.x.

FRANCISCHETTI, C.N., SILVA, E.R., SALLES, F.F. and NESSIMIAN, J.L., 2004. A Efemeropterofauna (Insecta: Ephemeroptera) do trecho ritral inferior do Rio Campo Belo, Itatiaia, RJ: composição e mesodistribuição. Lundiana, vol. 5, no. 1, pp. 33-39.

HENRIQUES-OLIVEIRA, A.L., NESSIMIAN, J.L. and DORVILLÉ, L.F.M., 2003. Feeding habitats of Chironomid larvae (Insecta: Diptera) from a stream in the Floresta da Tijuca, Rio de Janeiro, Brazil. Brazilian Journal of Biology $=$ Revista Brasileira de Biologia, vol. 63, no. 2, pp. 269-281. PMid:14509849. http:// dx.doi.org/10.1590/S1519-69842003000200012.

JACKSON, J.K. and SWEENEY, B.W., 1995. Egg and larval developmental cycles of central European times for 35 species of tropical stream insects from Costa Rica. Journal of the North American Benthological Society, vol. 14, pp. 115-130. http:// dx.doi.org/10.2307/1467728.

KOWNACKI, A., 1971. Taxocens of Chironomidae in streams of the Polish High Tatra Mts. (Str.). Acta Hydrobiologica, vol. 13, pp. 439-464.

LEAL, J.J.F., ENRICH-PRAST, A., ASSIS ESTEVES, F. BOZELLI, R. and FARJALLA, V.F., 2005. Influence of Campsurus notatus bioturbation on oxygen profile and uptake in sediments of an Amazonian lake impacted by bauxite tailings. Archiv für Hydrobiologie, vol. 162, no. 4, pp. 557-574. http://dx.doi. org/10.1127/0003-9136/2005/0162-0557.

LENAT, D., 1988. Water quality assessment using a qualitative collection method for benthic macroinvertebrates. Journal of the North American Benthological Society, vol. 7, no. 3, pp. 222-233. http://dx.doi.org/10.2307/1467422.

LUGO-ORTIZ, C.R. and MCCAFFERTY, W.P., 1996. Taxonomy of the Neotropical genus Americabaetis, new status (Insecta: Ephemeroptera: Baetidae). Studies on Neotropical Fauna and Environment, vol. 31, no. 3-4, pp. 156-169. http://dx.doi. org/10.1076/snfe.31.3.156.13341.

MACKAY, R.J., 1992. Colonization by lotic macroinvertebrates: a review of processes and patterns. Canadian Journal of Fisheries and Aquatic Sciences, vol. 49, no. 3, pp. 617-628. http://dx.doi. org/10.1139/f92-071.

MCCUNE, B. and MEFFORD, M.J., 1999. PC-ORD: Multivariate Analysis of Ecological Data. Version 4.0 [software] Gleneden Beach: MjM Software Design.

MELO, S.M., TAKEDA, A.M. and BUTTOW, N.C., 1993. Life history of nymphs of Campsurus violaceus Needham and Murphy, 1924 (Ephemeroptera, Polymitarcyidae) in the Baía River (MSBrasil). Revista Unimar, vol. 15, pp. 95-107. 
MELO, S.M., TAKEDA, A.M. and MONKOLSKI, A., 2002. Seasonal dynamics of Callibaetis willineri (Ephemeroptera, Baetidae) associated with Eichhornia azurea (Pontedericeae) in Guaraná Lake of the Upper Paraná River, Brazil. Hydrobiologia, vol. 470, no. 1/3, pp. 57-62. http://dx.doi.org/10.1023/A:1015617102463.

MELO, S.M., TAKEDA, A.M. and MONKOLSKI, A., 2004. Distribution of ephemeropteran nymphs associated with different stolon sections of Eichhornia azurea (Schwartz) in two floodplain lakes of the Upper Paraná River (Brazil). Polish Journal of Ecology, vol. 52, pp. 369-376.

NOLTE, U., OLIVEIRA, M.J. and STURS, E., 1997. Seasonal, discharge-driven patterns of mayfly assemblages in an intermittent Neotropical stream. Freshwater Biology, vol. 37, no. 2, pp. 333-343. http://dx.doi.org/10.1046/j.1365-2427.1997.00163.x.

PALMER, C., OKEEFFE, J., PALMER, A., DUNNE, T. and RADLOFF, S., 1993. Macroinvertebrate functional feeding groups in the middle and lower reaches of the Buffalo River, eastern Cape, South Africa. I. Dietary variability. Freshwater Biology, vol. 29, no. 3, pp. 441-453. http://dx.doi.org/10.1111/j.1365-2427.1993. tb00778.x

POLEGATTO, C.M. and FROEHLICH, C.G., 2001. Functional morphology of the feeding apparatus of the nymph of Farrodes sp. (Ephemeroptera: Leptophlebiidae). Acta Zoologica, vol. 82, no. 2, pp. 165-175. http://dx.doi.org/10.1046/j.1463-6395.2001.00083.x.

POWER, M.E., STOUT, J.R., CUSHING, C.E., HARPER, P.P., HAUER, R.F., MATTHEWS, W.J., MOYLE, P.B., STATZNER, B. and BADGEN, I.R.W., 1988. Biotic and abiotic controls in river and stream communities. Journal of the North American Benthological Society, vol. 7, no. 4, pp. 456-479. http://dx.doi. org/10.2307/1467301.

REYNOLDSON, T.B., NORRIS, R.H., RESH, V.H., DAY, K.E. and ROSENBERG, D.M., 1997. The reference condition: a comparison of multimetric and multivariate approaches to assess water-quality impairment using benthic macroinvertebrates. Journal of the North American Benthological Society, vol. 16, no. 4, pp. 833-852. http://dx.doi.org/10.2307/1468175.

SALLES, F.F., FRANCISCHETTI, C.N., ROQUE, F.O., PEPINELLI, M. and STRIXINO, S.T., 2003. Levantamento preliminar dos gêneros e espécies de Baetidae (Insecta: Ephemeroptera) do Estado de São Paulo, com ênfase em coletas realizadas em córregos florestados de baixa ordem. Biota Neotropica, vol. 3, no. 2, pp. 1-7. http:// dx.doi.org/10.1590/S1676-06032003000200011.

SALLES, F.F., SILVA, E.R., HUBBARD, M.D. and SERRÃO, J.E., 2004a. As espécies de Ephemeroptera (Insecta) registradas para o Brasil. Biota Neotropica, vol. 4, pp. 1-34.

SALLES, F.F., SILVA, E.R., SERRÃO, J.E. and FRANCISCHETTI, C.N., 2004b. Baetidae (Ephemeroptera) na Região Sudeste do Brasil: novos registros e chave para os gêneros no estágio ninfal. Neotropical Entomology, vol. 33, no. 6, pp. 725-735. http://dx.doi. org/10.1590/S1519-566X2004000600010.

SHIMANO, Y., JUEN, L., SALLES, F.F., NOGUEIRA, D.S. and CABETTE, H.S.R., 2013. Environmental and spatial processes determining Ephemeroptera (Insecta) structures in tropical streams Annuals of Limnology. Journal of International Limnology, vol. 49, no. 1, pp. 31-41. http://dx.doi.org/10.1051/limn/2013036.

SILVA, R.R., FEITOSA, R.S.M. and EBERHARDT, F., 2007. Reduced ant diversity along a habitat regeneration gradient in the southern Brazilian Atlantic Forest. Forest Ecology Management, vol. 240, pp. 61-69.

SOUZA FILHO, E.E. and STEVAUX, J.C., 1997. Geologia e geomorfologia do complexo rio Baia, Curutuba, Ivinheima. In: A.E.A.M. VAZZOLER, A.A. AGOSTINHO, N.S. HAHN, eds. A planície de inundação do alto rio Paraná: aspectos físicos, biológicos e socioeconômicos. Maringá: EDUEM, pp. 3-46.

SOUZA FILHO, E.E., 2009. Evaluation of the Upper Paraná River discharge controlled by reservoirs. Brazilian Journal of Biology = Revista Brasileira de Biologia, vol. 69, no. 2, suppl., pp. 707-716. http://dx.doi.org/10.1590/S1519-69842009000300024.

STEVAUX, J.C., SOUZA-FILHO, E.E. and JABUR, I.C., 1997. A história quaternária do rio Paraná em seu alto curso. In: A.E.A.M. VAZZOLER, A.A. AGOSTINHO, N.S. HAHN, eds. A planície de inundação do alto rio Paraná: aspectos fisicos, biológicos e socioeconômicos. Maringá: EDUEM, pp. 3-72.

STODDARD, J.L., HERLIHY, A.T., PECK, D.V., HUGHES, R.M., WHITTIER, R.T. and TARQUINIO, E., 2008. A process for creating multimetric indices for large-scale aquatic surveys. Journal of the North American Benthological Society, vol. 27, no. 4, pp. 878-891. http://dx.doi.org/10.1899/08-053.1.

SURIANO, M.T. and FONSECA-GESSNER, A.A., 2004. Chironomidade (Diptera) larvae in streams of Parque Estadual de Campos do Jordão, São Paulo state, Brazil. Acta Limnologica Brasiliensia, vol. 16, no. 2, pp. 129-136.

TAKEDA, A.M. and FUJITA, D.S., 2004. Benthic invertebrates. In: S.M. THOMAZ, A.A. AGOSTINHO, N.S. HAHN, eds. The upper River Paraná and its floodplain: physical aspects, ecology and conservation. Leiden: Blackhuys Publishers, pp. 191-208.

TAKEDA, A.M., SHIMIZU, G. and HIGUTI, J., 1997. Zoobentos da planície alluvial do alto rio Paraná. In: A.A. AGOSTINHO, A.E.M. VAZZOLER and N.S. HAHN, eds. A planície de inundação do alto rio Paraná; aspectos físicos, químicos, biológicos e Sócioeconômicos. Maringá: EDUEM, pp. 157-177.

TAKEDA, A.M., SOUZA-FRANCO, G.M., MELO, S.M. and MONKOLSKI, A., 2003. Invertebrados associados às macrófitas aquáticas na planície de inundação do alto rio Paraná (Brasil). In: S.M. THOMAZ and L.M. BINI, eds. Ecologia e manejo de macrófitas aquáticas. Maringá: EDUEM, pp. 243-260.

THOMAZ, S.M., ROBERTO, M.C., LANSAC-TÔHA, F.A., ESTEVES, F.A. and LIMA, A.F., 1991. Dinâmica temporal dos principais fatores limnológicos do rio Baía: planície de inundação do alto rio Paraná (MS-Brasil). Revista Unimar, vol. 13, p. 299-312.

VANNOTE, R.L., MINSHAL, G.W. CUMMINS, K.W., SEDELL., K.W. and CUSHING, C.E., 1980. The river continuum concept. Canadian Journal of Fisheries and Aquatic Sciences, vol. 37, no. 1 , p. 130-137.

WARD, J.V. and STANFORD, J.A., 1983. The serial discontinuity concept of lotic ecosystems. In: T.D.I. FONTAINE and S.M. BARTELL, eds. Dynamics of lotic ecosystems. Michigan: Ann Arbor Science. pp. 29-42.

WARD, J.V., 1992. Aquatic insect ecology: biology and habitat. New York: John Wiley and Sons. 438 p.

WELCOMME, R.L., 1985. River fisheries. Rome: FAO. 330 p. FAO Fisheries \& Aquaculture Technical Papers, no. 262. 